and breeding of ornamental species. Kluwer Academic, Dordrecht.

Trudel, J., C. Potvin, and A. Asselin. 1992. Expression of active hen egg white lysozyme in transgenic tobacco. Plant Sci. 87:55-67.

van den Bulk, R.W. 1991. Application of cell and tissue culture and in vitro selection for disease resistance breeding-A review. Euphytica 56:269285.

Walton, J.D. and D.G. Panaccione. 1993. Host-selective toxins and disease specificity: Perspectives and progress. Annu. Rev. Phytopathol. 31:275303.

Whealey, C.A. 1994. Vegetative geranium production: Cutting to the chase. GrowerTalks 58:34-43.
Wienand, U. and H. Saedler. 1987. Plant transposable elements: Unique structures for gene tagging, p. 205-227. In: T.H. Hohn and J. Schell (eds.). Plant DNA infectious agents. Springer Verlag, New York.

Wilmink, A., B.C.E. van den Ven, and J.J.M. Dons. 1992. Expression of the GUS-gene in the monocot tulip after introduction by particle bombardment and Agrobacterium. Plant Cell Rpt. 11:76-80.

Young, R. 1992. Bacteriophage lysis: Mechanism and regulation. Microbiol. Rev. 56:430-481.

Zasloff, M. 1987. Magainins, a class of antimicrobial peptides from Xenopus skin: Isolation, characterization of two active forms, and partial cDNA sequence of a precursor. Proc. Natl. Acad. Sci. USA 84:5449-5453.

\title{
Use of Random Amplified Polymorphic DNA Markers in Breeding for Major Gene Resistance to Plant Pathogens
}

\author{
James D. Kelly ${ }^{1}$ \\ Department of Crop and Soils Sciences, Michigan State University, East Lansing, MI 48824
}

\begin{abstract}
Markers are of interest to plant breeders as a source of genetic information on crops and for use in indirect selection of traits linked with the markers. Selection based on the marker would be more efficient provided there was tight linkage between the marker and the trait of interest $[<5$ centimorgans $(\mathrm{cM})]$ and assuming selection for the marker was more convenient (faster, cheaper, reproducible, expressed earlier). Markers for disease resistance offer the additional advantage of permitting selection for resistance in the absence of the pathogen or a variant of the pathogen. This feature is of particular interest to a plant breeder who may be reluctant either to work directly with or to introduce a pathogen where quarantine restrictions prevent its introduction. Markers linked to various resistance genes would greatly facilitate breeding for multiple disease resistance, since selection based on markers could be readily incorporated into a breeding program. This approach would be of particular interest with pathogens that exhibit inconsistent expression due to environmental or other factors. A single technology that would indirectly permit selection for diverse disease resistance genes would be highly desirable and extremely useful in breeding for disease resistance. Indirect selection as an efficient and practical means of developing disease-resistant cultivars will depend on the identification of markers that are easy to score and tightly linked to different resistance genes.
\end{abstract}

\section{TYPE OF MARKER}

Until recently, indirect selection has not been practical due to the lack of suitable markers, or the undesirable pleiotropic effects of many morphological markers. In recent years, marker-assisted selection (MAS) has received attention as a useful method for improving major gene disease resistance in horticultural crops. The concept of MAS, when applied to monogenic disease resistance, dictates that selection for one or more resistance genes is conducted by selecting a marker (or two flanking markers) tightly linked to the gene of interest (Melchinger, 1990). The use of this approach with morphological markers has been limited primarily due to the few such markers available in most crop

Received for publication 20 Oct. 1994. Accepted for publication 16 Nov. 1994. Research supported in part by grant DAN 1310-G-SS-6008-00 from the USAID Bean/Cowpea Collaborative Research Support Program, the Michigan Agricultural Experiment Station, and the U.S. Dept. of Agriculture (USDA)Agricultural Research Service. Mention of a trademark or a proprietary product does not constitute a guarantee or warranty of the product by the USDA and does not imply its approval to the exclusion of other products that may also be suitable. I acknowledge the assistance of L. Afanador, S.D. Haley, P.N. Miklas, J.R. Stavely, and R.A. Young in the development of RAPD markers in common bean and for their critical review of this manuscript. The cost of publishing this paper was defrayed in part by the payment of page charges. Under postal regulations, this paper therefore must be hereby marked advertisement solely to indicate this fact.

${ }^{1}$ Professor. species, their major effects on plant phenotype (often deleterious mutants), and the inability to score multiple morphological mutant traits in a single segregating population (Paterson et al., 1991). The development of markers based on allelic variants of specific enzymes (isozymes; Tanksley and Orton, 1983) and, most notably, of those based on variation in the length of DNA fragments obtained by digestion with restriction endonucleases (RFLPs; Botstein et al., 1980) has overcome these limitations.

RFLP markers offer significant advantages over isozymes. They demonstrate more detectable loci and alleles, are phenotypically neutral, and can be scored at any stage of plant development. RFLP markers have been used extensively to "tag" useful genes in common bean (Phaseolus vulgaris L., Degremont and Vallejos, 1994; Nodari et al., 1993), lettuce (Lactuca sativa L., Landry et al., 1987; Paran et al., 1991), pepper (Capsicum annuum L., Tanksley et al., 1988), potato (Solanum tuberosum L., Barone et al., 1990; Ritter et al., 1991), and tomato (Lycopersicon esculentum Mill., Klein-Lankhorts et al., 1991a; Nienhuis et al., 1987; Osborn et al., 1987; Sarfatti et al., 1991; Young et al., 1988). However, development of RFLP markers involves a tedious, expensive, multistep process that requires considerable investment in personnel, equipment, chemicals, and safety concerns if radioactive probes are used. The technology is not compatible with the needs of those breeders involved in resistance breeding and working with large populations and limited budgets.

Recently, a molecular marker based on the polymerase chain reaction (PCR) has been developed that alleviates these potential limitations. PCR was modified to develop a new form of molecular marker: the random amplified polymorphic DNA (RAPD) marker (Welsh and McClelland, 1990; Williams et al., 1990). Genetic mapping and gene tagging using RAPD markers has several advantages over other methods (Kesseli et al., 1992; Williams et al., 1990): 1) a universal set of primers can be used and screened in a short period, 2) no isolation of cloned DNA probes or preparation of hybridization filters is required, and 3) only small quantities of DNA are needed, allowing the use of simple and rapid methods for genomic isolation (Afanador et al., 1993; Edwards et al., 1991; Wang et al., 1993).

Since their inception, RAPDs have been used to tag major resistance genes in barley (Hordeum vulgare L., Barua et al., 1993), common bean (Haley et al., 1993, 1994a, 1994b, 1994c; Johnson and Gepts, 1994; Johnson et al., 1994; Jung et al., 1994; Miklas et al., 1993), lettuce (Kessili et al., 1992; Michelmore et al., 1991; Paran et al., 1991), oat (Avena sativa, L., Penner et al., 1993), rice (Oryza sativa L., Mohan et al., 1994), tomato (Klein-Lankhorts et al., 1991b; Martin et al., 1991; Williamson et al., 1994), and wheat (Triticum aestivum L., Schachermayr et al., 1994), and to assist in developing comprehensive genetic maps and within-species relationships in several plant species (alfalfa, Medicago sativa L., Echt et al., 1992; apple, Malus $\times$ domestica Borkh., Koller et al., 1993; blueberry, Vaccinium darrowi, Rowland and Levi, 1994; broccoli and cauliflower, Brassica oleracea L., Hu 
and Quiros, 1991; celery, Apium graveolens, Yang and Quiros, 1993; common bean, Jung et al., 1994, McClean et al., 1994, Nodari et al., 1993, Skroch et al., 1992; papaya, Carica papaya L., Stiles et al., 1993; peach, Prunus persica L. Batsch., Chaparro et al., 1994; soybean, Glycine $\max$ L. Merr., Williams et al., 1990; strawberry, Fragaria xananassa, Hancock et al., 1994; tomato, Foolad et al., 1993). Finally, Ragot and Hoisington (1993) have shown that cost per data point for RFLPs is less for large populations, while RAPDs are favored in smaller populations. This difference is probably immaterial in many self-pollinated crops where RFLPs lack a sufficient level of polymorphism within the species or between related breeding material (Nodari et al., 1992). RAPDs appear to detect higher levels of polymorphism and are more valuable in the construction of intraspecific genetic maps and in gene tagging research-an area where breeders are focusing currently (Haley et al., 1994d).

\section{STRUCTURE OF GENETIC POPULATIONS}

In most instances, identifying RFLPs or RAPDs linked to important resistant genes depends on the availability of pairs of backcrossderived, near-isogenic lines (NILs; Young et al., 1988). The development of NILs through backcrossing for economically important genes is costly and time consuming, but breeders have at their disposal lategeneration heterogeneous individuals within genetic populations from which NILs for a specific disease resistance trait can be isolated (Haley et al., 1994c). The use of such NILs has permitted the successful tagging of three disease resistance genes in common bean (Haley et al., 1994a, 1994b, 1994c).

An alternative strategy, bulked segregant analysis (Michelmore et al., 1991), was proposed recently to allow the rapid development of genetic populations useful for identifying RFLP or RAPD markers linked to disease resistance genes. With this method, Michelmore et al. (1991) identified three RAPD markers linked to major disease resistance genes using contrasting DNA bulks composed of $\mathrm{F}_{2}$ individuals of known genotype. Using backcross-derived populations segregating for two major rust resistance genes in common bean, Miklas et al. (1993) and Haley et al. (1993) have provided additional support for the utility of the bulked segregant method. Combining backcross introgression, characteristic of traditional NIL development, with bulked segregant analysis enhances the identification of markers that are tightly linked to the gene of interest (Haley et al., 1993; Michelmore et al., 1991; Miklas et al., 1993).

Another strategy used to facilitate gene tagging in common bean includes the creation of segregating populations where the resistance gene, originating from one gene pool, was introgressed directly or backcrossed into the other gene pool. Common bean is characterized by an extensive range of genetic variation. Biochemical, physiological, and morphological evidence strongly suggests that this variation is not distributed at random but is associated with two distinct centers of diversity commonly known as the Andean and Middle American gene pools (Gepts and Bliss, 1985; Gepts et al., 1986). This intergene-pool crossing technique was used successfully to tag two rust resistance genes in common bean (Haley et al., 1993; Miklas et al., 1993). Interspecific populations exploit the same concept to generate polymorphism for genetic mapping purposes (Paterson et al., 1990).

\section{RAPD MARKERS IN HORTICULTURAL CROPS}

PCR has been used successfully to identify RAPD markers linked to disease resistance genes in tomato, lettuce, and common bean. Martin et al. (1991) were the first to demonstrate the feasibility of using RAPD markers to tag the Pto gene, which confers resistance to Pseudomonas syringae pv. tomato in tomato. Michelmore et al. (1991) identified the first RAPD markers linked to the downy mildew resistance gene (Dm 5/8) in lettuce. Paran et al. (1991) have identified other RAPD markers linked to the $D m$ 1, 3, 4, 7, 13 genes. In common bean, Miklas et al. (1993) identified the first RAPD marker OA14 ${ }_{1100}$ tightly linked to the $U p$-2 rust resistance gene (no recombinants). Haley et al. (1993) identified the OF10 $0_{970}$ RAPD marker linked at $2.15 \mathrm{cM}$ from $B$ 190 and the OI19 $9_{460}$ marker tightly linked to the same $B-190$ rust resistance gene block (no recombinants), and the OK14 ${ }_{620}$ RAPD marker linked at $2.23 \mathrm{cM}$ from the $U r-3$ rust resistance gene (1994c). Young and Kelly (1994) tagged the Are anthracnose resistance gene with the OQ4 $4_{1440}$ RAPD marker (linked at $2.0 \mathrm{cM}$ ), while AdamBlodon et al. (1994) identified a second RAPD marker $\left(\mathrm{RoH}_{2} \mathrm{O}\right)$ linked at $0.5 \mathrm{cM}$ to the same gene.

\section{BREEDING STRATEGIES USING RAPDS}

Various breeding strategies have been employed for incorporating disease resistance. These strategies have involved the separate deployment of single gene resistance traits or the accumulation of multiple disease resistance traits into breeding lines. In many cases, resistance genes are lost in segregating populations derived from crosses with disease-susceptible lines since inadequate selection is practiced in plant breeding nurseries. Stavely et al. (1989) have indicated that obtaining stable rust resistance in common bean may necessitate pyramiding specific, broadly effective, resistance genes into traditional cultivars. The strategy of gene pyramiding is appealing when one considers that, in bean, the pyramid of the three rust resistance genes $U p-2$ with $B-190$ with $U r-3$ affords resistance to 63 of the 65 bean rust races characterized in the U.S. Dept. of Agriculture collection (Kelly et al., 1994). Only races 58 and 67 overcome the genes in this pyramid.

Schafer and Roelfs (1985) have provided support for gene pyramiding in spring wheat. No significant stem rust epidemic has occurred in North America since 1955 because contemporary spring wheat cultivars possess as many as six resistance genes. It is understandable that single resistance genes have not provided durable resistance to a highly variable rust pathogen, but a cultivar with four or five genes conditioning resistance to all races might remain resistant for many years if the gene-for-gene concept is valid. In common bean, breeders have the opportunity to exploit the complementation of Andean and Mesoamerican resistance genes and the partial duplication of different resistance genes from within the same gene pools. For example, the Andean $U p-2$ gene is complementary to the Mesoamerican $U r-3$ gene, while the Mesoamerican $B-190$ gene partially duplicates the action of the $U r-3$ gene when one considers the resistance to individual rust races that each confers.

\section{EPISTATIC INTERACTIONS}

In an effort to achieve these objectives, MAS offers the breeder a viable approach to developing cultivars with pyramided resistance genes (Stuber, 1991). The identification of RAPD markers tightly linked to resistance genes allows selection of the resistance gene indirectly since the expression of the molecular marker is not masked by epistatic interactions that occur between resistance genes. The current procedure of gene pyramiding is not practical for plant breeders because of the epistatic interaction between resistance genes. Since pyramiding requires that both epistatic and hypostatic genes be combined into a single genotype, breeders have no convenient way to select for the hypostatic gene without using multiple inoculations with different races or test-crosses with a susceptible genotype (Kelly et al., 1993). I have made three-way crosses to combine the three rust resistance genes (Up-2,Ur-3,B-190) into a single bean genotype, using linked RAPD markers to select for the three pyramided resistance sources. With the identification of additional markers linked to more broadly based rust resistance genes (Johnson et al., 1994) present in the U.S. plant introduction collection, more extensive gene pyramiding of these hypostatic genes is now possible. Gene pyramiding, using MAS, ensures the durability of those rust resistance genes that have been used extensively in bean breeding programs across the United States.

Currently, a similar situation exists in breeding for resistance to bean common mosaic virus (BCMV) in common bean. New temperature-insensitive, necrosis-inducing strains (NL 3, NL 8) of BCMV are pathogenic on the widely used $I$ gene resistance. As breeders incorporate the epistatic $b c-3$ resistance gene into a range of genotypes carrying the $I$ gene, the action of the $I$ gene is masked. This prevents breeders from distinguishing and selecting the more desirable $I b c-3$ recombinants from the single $b c-3$ genotypes. Using the OW $13_{690}$ 
marker linked to the $I$ gene, breeders can now select for the $I b c-3$ combination that affords pyramided resistance to all known strains of BCMV (Haley et al., 1994b).

\section{LINKAGE DISTANCES}

The distance between the marker and the resistance gene can dramatically affect the efficiency of MAS. Linkage to a trait of interest can vary depending on the populations studied. Differences in recombination distance facilitates mapping and genetic introgression across gene pools but becomes problematic when breeders are working with germplasm from similar genetic backgrounds. In common bean, RAPDs linked to genes introgressed from germplasm derived from a different gene pool appear to have lower recombinational frequencies and apparent tighter linkages than recombinational distances measured between the same linkage relationships present in genetic backgrounds from which the genes originated (Haley et al., 1994b). Genes from the Andean gene pool appear to exhibit tighter linkages with markers when measured in Middle American genetic backgrounds (Miklas et al., 1993). A similar trend has been observed with Middle American resistance genes in Andean backgrounds (Haley et al., 1993). However, the approach is confounded by RAPD markers that may be gene pool specific and of no value in selecting for the resistance gene in the same genetic background from which it originated. OA $14_{1100}$ could not be used for selection for the $U p-2$ Andean rust resistance gene in germplasm from the same gene pool. The value of the marker is restricted to the Middle American gene pool. This finding is in contrast to the RAPD $\left(\mathrm{OI} 19_{460}\right)$ linked to the Middle American $B-190$ gene where its use would be universal across all gene pools, regardless of origin of the resistance gene. The most desirable marker is one that retains the linkage with the resistance gene and is clearly expressed and functional across a broad range of genetic backgrounds. This feature has been demonstrated in beans for RAPD markers linked to the $U r-3$ rust resistance gene (Haley et al., 1994c) and the $I$ gene for BCMV resistance (Haley et al., 1994b); however, many studies are restricted to specific genetic populations and the usefulness of a linked marker is not demonstrated across a range of genotypes. Young and Kelly (unpublished data) showed that recombinational distances ranged from 2.0 to $5.5 \mathrm{cM}$ between two populations of common bean segregating for the Are anthracnose resistance gene and the OQ $4_{1440}$ RAPD marker. The apparent tight linkage observed in the inter-gene pool (wide) cross would suggest that linkage drag was restricting recombination in that cross but was less a factor in the related (intra-gene pool) cross. Linkage drag (Stam and Zeven, 1981; Zeven et al., 1983) between distantly related species overestimates levels of linkage in gene tagging and map construction (Paterson et al., 1990), resulting in markers that may be ineffective for many breeding programs that are restricted to within-species crosses. The application of a marker in breeding populations is more important to a plant breeder than the actual position of the marker in a genetic linkage map derived from a wide cross.

\section{SELECTION EFFICIENCY}

Efficiency of selection based on markers can be dramatically improved using a marker linked in repulsion with the resistance gene. A repulsion-phase marker is one linked with the susceptibility allele as compared with the more traditional marker linked in coupling with the resistance allele. Haley et al. (1994a) demonstrated that selection against a repulsion-phase RAPD provided a greater proportion of homozygous resistant genotypes and a lower proportion of both segregating and homozygous susceptible individuals than did selection for the coupling-phase RAPD. This was demonstrated for a recessive BCMV resistance gene $(b c-3)$ linked in coupling $(1.9 \mathrm{cM})$ with RAPD marker OAD19 ${ }_{690}$ and in repulsion $(7.1 \mathrm{cM})$ with RAPD marker OS13 ${ }_{660}$. Selection against a repulsion-phase marker linked at a 10-cM distance provided greater selection efficiency than 1-cM coupling-phase linkage, based on calculations of selection efficiency. This is particularly significant since recessive resistance genes require breeders to select against the heterozygous susceptible individuals. In addition, selection of individuals based on the phenotype of combined coupling and repulsion-phase RAPD markers was equivalent to selection based on a codominant marker (RFLP) and was identical to selection based on the repulsion-phase marker alone. Traditionally, work has focused on coupling-phase markers, but in terms of selection efficiency, these markers can be superseded by those linked in repulsion with the resistance gene. Breeders, in their search for markers, should put emphasis on markers linked with the disease susceptibility allele, since MAS for such a marker would be as efficient as selection based on codominant RFLPs in early segregating generations. However, coupling-phase markers are more useful in MAS used to quickly backcross a trait from an exotic source into an adapted line (Johnson et al., 1995). All possible $\mathrm{BC}_{n} \mathrm{~F}_{1}$ segregants useful as parents for the next cycle of backcrossing $(\mathrm{Rr})$ would carry the repulsion marker regardless of the level (generation) of backcrossing, while those with the resistance allele could be detected by a coupling-phase marker. Finally, selection based on linked RAPD markers can be as efficient as RFLP markers when used on advanced-generation recombinant inbred lines (RILs), where the level of heterozygosity is minimal. Delaying selection until later generations may be a desirable strategy, since dominant resistance genes would have a higher probability of being fixed at this stage.

\section{Use of recombinants to facilitate MAS}

In those instances where a linked marker is present in resistant and susceptible germplasm ( $U p-2$ gene in bean; Miklas et al., 1993), breeders could use recombinant individuals from the mapping population as parents in MAS for disease resistance. Within segregating mapping populations, a low frequency of recombinants is generally observed between the marker and resistance gene. Those recombinants that carry the resistance gene but not the marker can be used as parents to introgress the same resistance gene into susceptible genotypes that possess the marker. In this instance, selection against the marker (repulsion linkage) would be practiced to identify resistant individuals. This has been successfully demonstrated in common bean (Miklas, unpublished data) and affords the opportunity to use MAS in segregating germplasm, which, because of origin (gene pool), would be precluded from such studies. Selection against a marker would have increased efficiency (Haley et al., 1994a). A similar situation arises with repulsion-phase markers that could be converted to couplingphase markers by selecting as parents those recombinant individuals that are resistant but carry the marker. In this case, selection would be less efficient because the breeder is selecting for a marker linked in coupling.

\section{REPRODUCIBILITY}

Lack of reproducibility or reliability is not an unexpected problem with a new technology. Similar difficulties were originally encountered in the development of isozyme markers but were later eliminated. Problems with reliability have occurred in the development of RAPD markers (Weeden et al., 1992), but those laboratories that persisted with the technology have clearly demonstrated the consistent reproducibility of linked RAPDs over time and material (Haley et al., 1994c). Sources of variability lie in the choice of thermal-stable DNA polymerase and thermal cycler used in PCR amplification, or in imprecise matches between the short oligonucleotide primers (decamers) and the template DNA at the low annealing temperatures (35-40C) typical of these types of studies. Discrepancies between laboratories have been observed because of these variables. To address these concerns and those over map-based cloning, sequenced-characterized amplified regions (SCARs) have been developed by Kesseli et al. (1992) and Paran and Michelmore (1993) in lettuce. A similar marker described as allele-specific associated primers (ASAPs) has been developed by Weeden et al. (1992) in common bean. Reproducibility is increased by sequencing the two ends of the RAPD fragment and synthesizing two longer primers $(\approx 24$ base pairs $)$ homologous to each end. These two primers (ASAPs), which include the original decamer sequence, are used in the same PCR protocol, but at elevated annealing temperatures (50-65C), and generally produce a single fragment (SCAR) equivalent to that previously sequenced. Paran and 
Michelmore (1993) developed SCARs for eight RAPD markers linked to downy mildew $(\mathrm{Dm})$ resistance genes in lettuce, and Adam-Blondon et al. (1994) developed a SCAR linked to the anthracnose (Are) resistance gene in common bean. The majority of SCARs amplified single major bands the same size as the original RAPD fragment. Since only a single band is amplified, the electrophoretic step can be eliminated because the amplified DNA can be visualized easily by staining with ethidium bromide. The latter technique has been demonstrated successfully using ASAPs linked to photoperiod genes in common bean (Gu et al., 1994), and application of the technique to tagging resistance genes in common bean has been reported by Weeden (personal communication). The presence or absence of amplified DNA would similarly indicate presence or absence of the linked resistance gene. When screened on thermal cyclers adapted for microtiter plates, many samples can be screened quickly with limited personnel.

\section{SUMMARY}

Molecular markers can potentially increase the importance and usefulness of indirect selection in plant breeding. In the past, MAS was not widely practiced because of ineffective linkages or the relative inefficiency of selection for a marker due to either incomplete or masked expression or low heritability. Molecular markers are not replacements for classical resistance breeding techniques. They assist breeders in improving efficiency and permitting the successful pyramiding of resistance genes where epistasis is involved, thus improving durability of these resistance sources. RAPD markers provide a useful technology that afford breeders alternative approaches to breeding for durable resistance. The technology will add to the arsenal of tools available to the applied plant breeder active in disease resistance breeding. The opportunity to select for disease resistance in the absence of the pathogen opens new possibilities to breeders where either inexperience with a pathogen or quarantine regulations restricting its entry are major obstacles.

RAPD markers tightly linked to major resistance genes have been identified in various horticultural crops and will facilitate the development of more disease-resistant cultivars. The next advance in this technology, designed to overcome problems with reproducibility across laboratories, will be the development of sequence or allelespecific primers (SCARs, ASAPs) for a resistance gene once the original polymorphism has been identified using the random primers. The ASAP primers are longer in sequence and usually result in the amplification of a single band, which can eliminate the need for electrophoresis, thus making the identification simpler and more efficient. Selection for resistance genes linked to SCARs will be rapid and less expensive. MAS will become more valuable as additional markers linked to different resistance genes are identified in individual crops. The application of molecular markers to breeding represents an excellent example of the successful use of indirect selection for disease resistance.

\section{Literature Cited}

Adam-Blondon, A.F., M. Sévignac, H. Bannerot, and M. Dron. 1994. SCAR, RAPD and RFLP markers linked to a dominant gene (Are) conferring resistance to anthracnose in common bean. Theoretical Applied Genet. 88:865-870.

Afanador, L.K., S.D. Haley, and J.D. Kelly. 1993. Adoption of a 'mini-prep' DNA extraction method for RAPD marker analysis in common bean (Phaseolus vulgaris). Ann. Rpt. Bean Improvement Coop. 36:10-11.

Barone, A., E. Ritter, U. Schachtschabel, T. Debener, F. Salamini, and C. Gebhardt. 1990. Localization by restriction fragment length polymorphism mapping in potato of a major dominant gene conferring resistance to the potato cyst nematode Globodera rostochiensis. Mol. Gen. Genet. 224:177182.

Barua, U.M., K.J. Chalmers, C.A. Hackett, W.T.B. Thomas, W. Powell, and R. Waugh. 1993. Identification of RAPD marker linked to a Rhynchosporium secalis resistance locus in barley using near isogenic lines and bulked segregant analysis. Heredity 71:177-184.

Botstein, D., R.L. White, M. Skolnick, and R.W. Davis. 1980. Construction of a linkage map in man using restriction fragment length polymorphisms. Amer. J. Human Genet. 32:314-331.
Chaparro, J.X., D.J. Werner, D. O'Malley, and R.R. Sederoff. 1994. Targeted mapping and linkage analysis of morphological isozymes, and RAPD markers in peach. Theoretical Applied Genet. 87:805-815.

Degremont, I.V. and C.E. Vallejos. 1994. Isolation of markers tightly linked to a virus resistance gene ( $I$ ) of the common bean. Proc. Plant Genome II P41. p. 25.

Echt, C.S., L.A. Erdahl, and T.J. McCoy. 1992. Genetic segregation of random amplified polymorphic DNA in diploid cultivated alfalfa. Genome 35:8487.

Edwards, K.C., C. Johnstone, and C. Thompson. 1991. A simple and rapid method for the preparation of plant genomic DNA for PCR analysis. Nucleic Acids Res. 19:1349.

Foolad, M.R., R.A. Jones, and R.L. Rodriguez. 1993. RAPD markers for constructing intraspecific tomato genetic maps. Plant Cell Rpt. 12:293297.

Gepts, P. and F.A. Bliss. 1985. $\mathrm{F}_{1}$ hybrid weakness in the common bean. J. Hered. 76:447-450.

Gepts, P., T.C. Osborn, K. Rashka, and F.A. Bliss. 1986. Phaseolin protein variability in wild forms and landraces of the common bean (Phaseolus vulgaris): Evidence for multiple centers of domestication. Econ. Bot. 40:451-468.

Gu W.-K., N. Weeden, and D. Wallace. 1994. A technique adaptable to high sample number processing for marker assisted selection and other DNAbased screening applications. Proc. Plant Genome II P73. p. 33.

Haley, S.D., L.K. Afanador, and J.D. Kelly. 1994a. Selection for monogenic resistance traits with coupling- and repulsion-phase RAPD markers. Crop Sci. 34:1061-1066.

Haley, S.D., L. Afanador, and J.D. Kelly. 1994b. Identification and application of a random amplified polymorphic DNA marker for the I gene (potyvirus resistance) in common bean. Phytopathology 84:157-160.

Haley, S.D., L.K. Afanador, P.N. Miklas, J.R. Stavely, and J.D. Kelly. 1994c. Heterogeneous inbred populations are useful as sources of near-isogenic lines from RAPD marker localization. Theoretical Applied Genet. 88:337342.

Haley, S.D., P.N. Miklas, L. Afanador, and J.D. Kelly. 1994d. Random amplified polymorphic DNA (RAPD) marker variability between and within gene pools of common bean. J. Amer. Soc. Hort. Sci. 119:122-125.

Haley, S.D., P.N. Miklas, J.R. Stavely, J. Byrum, and J.D. Kelly. 1993. Identification of RAPD markers linked to a major rust resistance gene block in common bean. Theoretical Applied Genet. 86:505-512.

Hancock J.F., P.A. Callow, and D.V. Shaw. 1994. Randomly amplified polymorphic DNAs in the cultivated strawberry, Fragaria $\times$ ananassa. J. Amer. Soc. Hort. Sci. 119:862-864.

$\mathrm{Hu}$, J. and C.F. Quiros. 1991. Identification of broccoli and cauliflower cultivars with RAPD markers. Plant Cell Rpt. 10:505-511.

Johnson, E., P.N. Miklas, and J.R. Stavely. 1994. The potential of coupling and repulsion phase RAPD markers for indirect selection of rust resistance progeny in common bean. Ann. Rpt. Bean Improv. Coop. 37:81-82.

Johnson, E., P.N. Miklas, J.R. Stavely, and J.C. Martinez-Cruzado. 1995. Coupling and repulsion RAPD markers for marker-assisted selection of a rust resistance gene in common bean. Theoretical Applied Genet. (In press.)

Johnson, W.C. and P. Gepts. 1994. Two new molecular markers linked to bc3. Ann. Rpt. Bean Improvement Coop. 37:206-207.

Jung, G., D.P. Coyne, P.W. Skroch, J. Nienhuis, E. Arnaud-Santana, J. Bokosi, S.M. Kaeppler, and J.R. Steadman. 1994. Construction of a genetic linkage map and locations of common blight, rust resistance and pubescence loci in Phaseolus vulgaris L. using RAPD markers. Ann. Rpt. Bean Improvement Coop. 37:37-38.

Kelly, J.D., P.N. Miklas, J.R. Stavely, L. Afanador, and S.D. Haley. 1994. Application of RAPD markers for disease resistance breeding in beans. Ann. Rpt. Bean Improvement Coop. 37:15-16.

Kelly, J.D., J.R. Stavely, P. Miklas, L. Afanador, and S.D. Haley. 1993. Pyramiding rust resistance genes using RAPD markers. Ann. Rpt. Bean Improvement Coop. 36:166-167.

Kesseli, R.V., I. Paran, and R.W. Michelmore. 1992. Efficient mapping of specifically targeted genomic regions and the tagging of these regions with reliable PCR-based genetic markers. Crop Sci. Soc. Amer.-Amer. Soc. Hort. Sci.-Amer. Genet. Assn. Joint Plant Breeding Symp. Ser., Minneapolis. Crop Sci. Soc. Amer., Madison, Wis. p. 31-36.

Klein-Lankhorts R., P. Rietveld, R. Verkerk, R. Weide, C. Gebhardt, M. Koornneef, and P. Zabel. 1991a. RFLP markers linked to the root knot nematode resistance gene $M i$ in tomato. Theoretical Applied Genet. 81:661667.

Klein-Lankhorts, R.M., A. Vermunt, R. Weide, T. Liharska, and P. Zabel. 1991b. Isolation of molecular markers for tomato (L. esculentum) using random amplified polymorphic DNA (RAPD). Theoretical Applied Genet. 83:108-114.

Koller, B., A. Lehmann, J.M. McDermott, and C. Gessler. 1993. Identification 
of apple cultivars using RAPD markers. Theoretical Applied Genet. 85:904906.

Landry, B.S, R.V. Kesseli, B. Farrar, and R.W. Michelmore. 1987. A genetic map of lettuce (Lactuca sativa L.) with restriction fragment length polymorphism, isozyme, disease resistance and morphological markers. Genetics 116:331-337.

Martin, G.B., J.G.K. Williams, and S.D. Tanksley. 1991. Rapid identification of markers linked to a Pseudomonas resistance gene in tomato by using random primers and near-isogenic lines. Proc. Natl. Acad. Sci. USA 88:2336-2340.

McClean, P., J. Ewing, M. Lince, and K. Grafton. 1994. Development of a RAPD map of Phaseolus vulgaris L. Ann. Rpt. Bean Improvement Coop. 37:79-80.

Melchinger, A.E. 1990. Use of molecular markers in breeding for oligogenic disease resistance. Plant Breeding 104:1-19.

Michelmore, R.W., I. Paran, and R.V. Kesseli. 1991. Identification of markers linked to disease resistance genes by bulked segregant analysis: A rapid method to detect markers in specific genomic regions using segregating populations. Proc. Natl. Acad. Sci. USA 88:9828-9832.

Miklas, P.N., J.R. Stavely, and J.D. Kelly. 1993. Identification and potential use of a molecular marker for rust resistance in common bean. Theoretical Applied Genet. 85:745-749.

Mohan, M., S. Nair, J.S. Bentur, U.P. Rao, and J. Bennett. 1994. RFLP and RAPD mapping of the rice $G m 2$ gene that confers resistance to biotype 1 of gall midge (Orseolia oryzae). Theoretical Applied Genet. 87:782-788.

Nienhuis, J., T. Helentjaris, M. Slocum, B. Ruggero, and A. Schaefer. 1987. Restriction fragment length polymorphism analysis of loci associated with insect resistance in tomato. Crop Sci. 27:797-803.

Nodari, R.O., E.M.K. Koinange, J.D. Kelly, and P. Gepts. 1992. Towards an integrated linkage map of common bean. I. Development of genomic DNA probes and levels of restriction fragment length polymorphism. Theoretical Applied Genet. 84:186-192.

Nodari, R.O., S.M. Tsai, R.L. Gilbertson, and P. Gepts. 1993. Towards an integrated linkage map of common bean. 2. Development of an RFLPbased linkage map. Theoretical Applied Genet. 85:513-520.

Osborn, T.C., D.C. Alexander, and J.F. Fobes. 1987. Identification of restriction fragment length polymorphisms linked to genes controlling soluble solids content in tomato fruit. Theoretical Applied Genet. 73:350-356.

Paran, I., R.V. Kesseli, and R.W. Michelmore. 1991. Identification of restriction fragment length polymorphism and random amplified polymorhphic DNA markers linked to downy mildew resistance genes in lettuce, using near-isogenic lines. Genome 34:1021-1027.

Paran, I. and R.W. Michelmore. 1993. Development of reliable PCR-based markers linked to downy mildew resistance genes in lettuce. Theoretical Applied Genet. 85:985-993.

Paterson, A.H., J.W. DeVerna, B. Lanini, and S.D. Tanksley. 1990. Fine mapping of quantitative trait loci, using selected overlapping recombinant chromosomes, in an interspecific cross of tomato. Genetics 124:735-742.

Paterson, A.H., S.D. Tanksley, and M.E. Sorrells. 1991. DNA markers in plant improvement. Advances Agron. 46:39-90.

Penner, C.A., J. Chong, M. Levesque-Lemay, S.J. Molnar, and G. Fedak. 1993. Identification of a RAPD marker linked to oat stem rust gene $P g 3$. Theoretical Applied Genet. 85:702-705.

Ragot, M. and D.A. Hoisington. 1993. Molecular markers for plant breeding: Comparisons of RFLP and RAPD genotyping costs. Theoretical Applied Genet. 86:975-984.

Ritter, E., T. Debener, A. Barone, F. Salamini, and C. Gebhardt. 1991. RFLP mapping on potato chromosomes of two genes conferring resistance to potato virus X (PVX). Mol. Gen. Genet. 227:81-85.
Rowland, L.J. and A. Levi. 1994. RAPD-based genetic linkage map of blueberry derived from a cross between diploid species (Vaccinium darrowi and $V$. elliottii). Theoretical Applied Genet. 87:863-868.

Sarfatti, M., M.A. Abied, J. Katan, and D. Zamir. 1991. RFLP mapping of I1, a new locus in tomato conferring resistance against Fusarium oxysporum F. sp. lycopersici race 1. Theoretical Applied Genet. 82:22-26.

Schachermayr, G., H. Siedler, M.D. Gale, H. Winzeler, M. Winzeler, and B. Keller. 1994. Identification and localization of molecular markers linked to the $\operatorname{Lr} 9$ leaf rust resistance gene of wheat. Theoretical Applied Genet. $88: 110-115$.

Schafer, F.R. and A.P. Roelfs. 1985. Estimated relation between numbers of urediniospores of Puccinia graminis f. sp. tritici and rates of occurrence of virulence. Phytopathology 75:749-750.

Skroch, P., J. Tivang, and J. Nienhuis. 1992. Analysis of genetic relationships using RAPD marker data. Applications of RAPD technology to plant breeding. Crop Sci. Soc. Amer.-Amer. Soc. Hort. Sci--Amer. Genet. Assn. Joint Plant Breeding Symp. Ser., Minneapolis. Crop Sci. Soc. Amer., Madison, Wis. p. 26-30.

Stam, P. and A.C. Zeven. 1981. The theoretical proportion of the donor genome in near-isogenic lines of self-fertilizers bred by backcrossing. Euphytica 30:227-238.

Stavely, J.R., J.R. Steadman, and R.J. McMillian, Jr. 1989. New pathogenic variability in Uromyces appendiculatus in North America. Plant Dis. 73:428-432.

Stiles, J.I., C. Lemme, S. Sondur, M.B. Morshidi, and R. Manshardt. 1993. Using randomly amplified polymorphic DNA for evaluating genetic relationships among papaya cultivars. Theoretical Applied Genet. 85:697701.

Stuber, C.W. 1991. Biochemical and molecular markers in plant breeding. Plant Breeding Rev. 9:37-61.

Tanksley, S.D, R. Bernatzky, N.L. Lapitan, and J.P. Prince. 1988. Conservation of gene repertoire but not gene order in pepper and tomato. Proc. Natl. Acad. Sci. USA 85:6419-6423.

Tanksley, S.D. and T.J. Orton. 1983. Isozymes in plant genetics and breeding, Parts 1A and 1B. Elsevier, Amsterdam, Netherlands.

Wang, H., M. Qi, and A.J. Culter. 1993. A simple method of preparing plant samples for PCR. Nucleic Acids Res. 21:4153-4154.

Weeden, N.F., G.M. Timmerman, M. Hemmat, B.E. Kneen, and M.A. Lodhi. 1992. Inheritance and reliability of RAPD markers. Crop Sci. Soc. Amer.Amer. Soc. Hort. Sci.-Amer. Genet. Assn. Joint Plant Breeding Symp. Ser., Minneapolis. Crop Sci. Soc. Amer., Madison, Wis. p. 12-17.

Welsh, J. and M. McClelland. 1990. Fingerprinting genomes using PCR with arbitrary primers. Nucleic Acids Res. 18:7213-7218.

Williams, J.G.K., A.R. Kubelik, K.J. Livak, J.A. Rafalksi, and S.V. Tingey. 1990. DNA polymorphisms amplified by arbitrary primers are useful as genetic markers. Nucleic Acids Res. 18:6531-6535.

Williamson, V.M., J.-Y. Ho, F.F. Wu, N. Miller, and I. Kaloshian. 1994. A PCR-based marker tightly linked to the nematode resistance gene, $M i$, in tomato. Theoretical Applied Genet. 87:757-763.

Yang, X. and C. Quiros. 1993. Identification and classification of celery cultivars with RAPD markers. Theoretical Applied Genet. 86:205-212.

Young, N.D., D. Zamir, M.W. Ganal, and S.D. Tanksley. 1988. Use of isogenic lines and simultaneous probing to identify DNA markers tightly linked to the Tm-2a gene in tomato. Genetics 120:579-585.

Young, R.A. and J.D. Kelly. 1994. A RAPD marker for the $A R E$ anthracnose resistance gene in beans. Ann. Rpt. Bean Improvement Coop. 37:77-78.

Zeven, A.C., D.R. Knott, and R. Johnston. 1983. Investigation of linkage drag in near isogenic lines of wheat by testing for seedling reaction to races of stem rust, leaf rust and yellow rust. Euphytica 32:319-327. 